\title{
FDI IN TOURISM SECTOR AND ECONOMIC GROWTH IN SUMATRA UTARA
}

\author{
Parhimpunan Simatupang ${ }^{1}$; Abdul Razak Chik ${ }^{2}$ \\ ${ }^{1}$ Business Administration and Humanities Faculty, Swiss German University \\ EduTown BSDCity, Tangerang 15339, Indonesia \\ ${ }^{2}$ School of Economics, Finance \& Banking, Universiti Utara Malaysia \\ Sintok, 06010 Universiti Utara Malaysia, Kedah, Malaysia \\ ${ }^{1}$ parhimpunan.simatupang@sgu.ac.id; ${ }^{2}$ arc@uum.edu.my
}

\begin{abstract}
Globalization and neo liberal policies such as liberalization and privatization have generated a significant growth for FDI and considered an important source for capital and foreign currency, capable of spurring economic growth in developing countries. One sector that received particular attention, due to its significant contributions towards economic development, especially in Indonesia, is tourism. Tourism investments in Indonesia are mainly focused on the development of fully-integrated resort sites that help boost the construction of tourist facilities such as hotels and the development of the surrounding environment through social and cultural aspects. The total contribution of travel and tourism to GDP was IDR736.3 billion or $8.9 \%$ of GDP in 2012. Foreign direct tourism investments grew by 210\% between 2011 and 2012, or at an annual compound average growth rate of 38\% between 2006 and 2012. While the implications are at national level, not much could be gathered on the local perspectives. This paper intends to explore the implication of FDI in tourism sector towards economic growth in one of tourism attraction provinces in Indonesia-Sumatra Utara. Specifically, which economic factors contributed towards FDI inflows and their impacts on economic growth in Sumatra Utara.
\end{abstract}

Keywords: economic growth, FDI, tourist attraction, tourism

\begin{abstract}
ABSTRAK
Globalisasi dan kebijakan neoliberal seperti liberalisasi dan privatisasi telah menghasilkan pertumbuhan yang signifikan bagi FDI dan dianggap sebagai sumber penting untuk modal dan mata uang asing, maтри тетаси pertumbuhan ekonomi di negara-negara berkembang. Salah satu sektor yang mendapat perhatian khusus, karena kontribusi yang signifikan terhadap pembangunan ekonomi, khususnya di Indonesia, adalah pariwisata. Investasi pariwisata di Indonesia terutama difokuskan pada pengembangan situs resor terintegrasi yang membantu untuk meningkatkan pembangunan fasilitas wisata seperti hotel dan pengembangan lingkungan sekitarnya melalui aspek sosial dan budaya. Total kontribusi perjalanan dan pariwisata terhadap PDB 736.3 miliar rupiah atau 8,9\% dari PDB pada 2012. Investasi pariwisata asing langsung tumbuh $210 \%$ antara tahun 2011 dan 2012, atau pada tingkat pertumbuhan tahunan gabungan rata-rata $38 \%$ antara tahun 2006 dan 2012. Sementara implikasi di tingkat nasional, tidak banyak yang bisa dikumpulkan pada perspektif lokal. Tulisan ini bermaksud untuk mengeksplorasi implikasi dari FDI di sektor pariwisata terhadap pertumbuhan ekonomi di salah satu pariwisata yang menarik di Indonesia-Sumatra Utara. Secara khusus, faktor-faktor ekonomi berkontribusi terhadap arus masuk FDI dan dampaknya terhadap pertumbuhan ekonomi di Sumatra Utara.
\end{abstract}

Kata kunci: pertumbuhan ekonomi, FDI, daya tarik wisata, pariwisata 


\section{INTRODUCTION}

Recently, it has been established that tourism has become one of the most significant export sectors in many developing countries and it not only increases foreign exchange income, but also creates employment opportunities, stimulates the growth of the tourism industry triggers overall economic growth (Samimi, Sadeghi, \& Sadeghi, 2013). Tourism is one of the world's largest industries accounting for over one-third of total global service trade (Endo, 2006). Tourism industry agglomerates many separate activities that come together in the production and consumption of tourism (UNCTAD, 2008). Foreign Direct Investment (FDI) is one of the routes through which developing countries can carry out tourism, but the dynamics of FDI in this dynamic sector, and its implications, have been relatively little studied. There is very little empirical information about the extent of tourism-related FDI in the global economy or its overall impact (UNCTAD, 2007). Foreign Direct Investment (FDI) in tourism would help developing countries to mitigate the effect of adverse development gap between developed and developing countries (UNCTAD, 2007).

The economic impacts of tourism can be measured in many terms, such as output, income, employment, value added, taxes, etc. The magnitude of the relative impacts depends upon the relative magnitude of the direct and the derived effects. The magnitude of direct effects can be decomposed into four factors: tourist intensity, the level of daily consumption for the type of overnight stay, the composition of tourist activity by the type of overnight stay, and employment content of tourist related activity/the opportunity of jobs seekers (Zhang, Madsen, \& Jensen-Butler, 2007). Tourism investment in Indonesia grew by more than $210 \%$ from 2011 to 2012. The growth in tourism investment is aligned with the country's positive economic growth. Additionally, the Indonesian government has been instrumental in streamlining investment procedures and promoting investment opportunities and potential of Indonesia within the region, resulting in a favourable investment environment as shown by figure 1 .

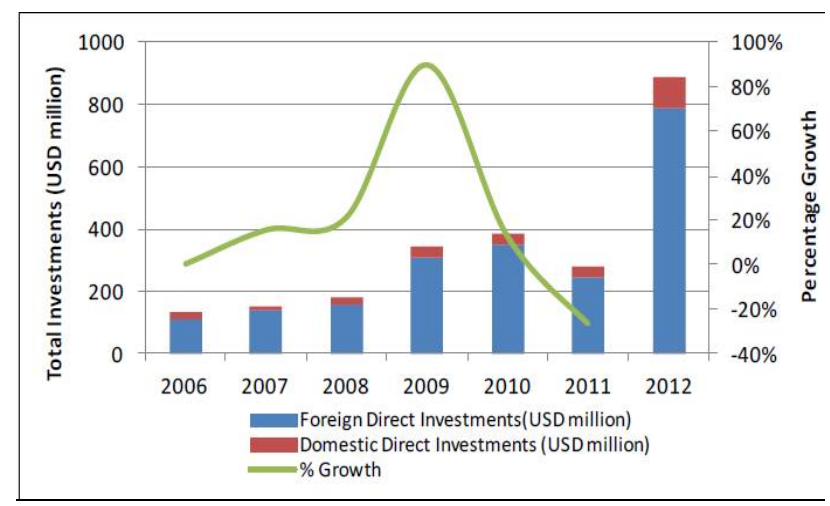

Figure 1 Tourism Investments, Indonesia 2006 - 2012 (Source: Indonesia Investment Coordinating Board, 2013)

\section{North Sumatra Tourism Sector FDI Realization Based on Business Type}

Table 1 exposes that the realization of FDI based on business type has slightly increased. The largest FDI for Star Hotel business type occurred in 2012 with the investment amount of US\$ 729,724 Million. From 2010 until 2014, FDI for Homestay business type only occurred in 2012 with the investment amount of US\$ 0.35 Million. The highest FDI for Restaurant and Roving Food Supply business type occurred in 2013 with the amount of US\$ 13,589 Million. From 2010 to 2013, the highest FDI in the tourism sector occurred in 2012 with the amount of US\$ 768.50 Million. In 2013, 
tourism sector FDI fell as much as $39.8 \%$ to US\$ 462.47 million. In the first quarter (Q1) 2014, tourism sector FDI reached US\$117.24 million as shown by Table 1. FDI in North Sumatra is slightly increased. In 2010, the FDI conveyed to North Sumatra US \$ 270 Million and 2011 was increased to US \$ 4.672 Million. In the year of 2012 to 2013 was going down by contributed from US \$ 4.143 Million to US \$ 1.735 Million only. But in the first quarter the year of 2014 rebound again to US \$ 2.503 Million. Overall, Tourism sector in North Sumatra until the first quarter of 2014 contributed US \$13.331 Million.

Table 1 FDI Realization Based on Business Type in North Sumatra

\begin{tabular}{|c|c|c|c|c|c|c|}
\hline \multirow{2}{*}{ No } & \multirow{2}{*}{ Type of Business } & \multicolumn{5}{|c|}{ FDI (Million US\$) } \\
\hline & & 2010 & 2011 & 2012 & 2013 & 2014-Q1 \\
\hline 1 & Star Hotel & 309.085 & 197.552 & 729.724 & 383.267 & 67.892 \\
\hline 2 & Melati Hotel & 0.69 & 1.63 & 0.79 & 2.295 & 2.298 \\
\hline 3 & Homestay & - & - & 0.35 & - & - \\
\hline 4 & $\begin{array}{l}\text { Other Short Term Accommodation } \\
\text { Provision }\end{array}$ & 26.708 & 33.838 & 28.696 & 60.159 & 44.45 \\
\hline 5 & Other Accommodation Provision & 0.06 & 4.602 & 0.005 & 0.611 & - \\
\hline 6 & Restaurant and Food Roving Supply & 10.063 & 4.372 & 8.576 & 13.589 & 2.6 \\
\hline 7 & Catering Services for Specific Event & - & 0.25 & 0.009 & 0.284 & - \\
\hline 8 & Beverages Supply & - & - & 0.35 & 2.32 & - \\
\hline & Total & 346.606 & 242.244 & 768.5 & 462.525 & 117.24 \\
\hline
\end{tabular}

\section{North Sumatra Regional Economic Performance}

The economic performance of North Sumatra Province from the year of 2010 to 2012 (see Table 2) was slightly increased. This performance indicator contributed by the sector of Hotel and Restaurant. In 2010, Hotel and Restaurant was offered $11 \%$ from the total income regional in this particular year 2010 is 2,158.6 Millions US\$. In 2011, contributed also contributed $11 \%$ although the total income increased to 2,306.6 Millions US\$. In 2012, Hotel and restaurant conveyed $10.8 \%$ and small decreased from the previous year as referred to table 2. The purpose of this research is to investigates the significance Foreign Direct Investment in tourism sector relates to implications of Economic Growth in North Sumatra.

Table 2 North Sumatra Regional Economic Performance:

GDP Province Based on Industrial (IDR/US Billion) with current price

\begin{tabular}{|c|c|c|c|c|c|c|c|c|c|c|}
\hline \multirow{2}{*}{ Industrial Origin } & \multicolumn{2}{|c|}{ Current Price 2010} & \multicolumn{2}{|c|}{ Current Price 2011} & \multicolumn{2}{|c|}{ Current Price 2012} & \multicolumn{2}{|c|}{ Current Price 2013} & \multicolumn{2}{|c|}{$\begin{array}{c}\text { Current Price } 2014 \\
\text { Q1 }\end{array}$} \\
\hline & IDR & USD & IDR & USD & IDR & USD & IDR & USD & IDR & USD \\
\hline 1. Agriculture & $63,181.84$ & 5.2652 & $70,655.87$ & 5.8880 & $76,838.11$ & 6.4032 & $86,118.60$ & 7.1766 & $46,139.74$ & 3.8450 \\
\hline 2. Mining and Quarrying & $3,789.75$ & 0.3158 & $4,341.19$ & 0.3618 & $4,635.32$ & 0.3863 & $5,252.87$ & 0.4377 & $2,802.05$ & 0.2335 \\
\hline 3. Manufacturing & $63,293.45$ & 5.2745 & $70,672.27$ & 5.8894 & $77,484.96$ & 6.4571 & $87,170.66$ & 7.2642 & $46,624.40$ & 3.8854 \\
\hline $\begin{array}{l}\text { 4. Electricity, Gas \& } \\
\text { Water Supply }\end{array}$ & $2,609.89$ & 0.2175 & $2,966.27$ & 0.2472 & $3,150.34$ & 0.2625 & $3,430.43$ & 0.2859 & $1,860.26$ & 0.1550 \\
\hline 5. Construction & $17,519.79$ & 1.4600 & $20,172.80$ & 1.6811 & $23,595.94$ & 1.9663 & $27,934.64$ & 2.3279 & $15,069.82$ & 1.2558 \\
\hline $\begin{array}{l}\text { 6. Trade, Hotel \& } \\
\text { Restaurant }\end{array}$ & $52,384.32$ & 4.3654 & $60,387.52$ & 5.0323 & $67,027.28$ & 5.5856 & $77,918.68$ & 6.4932 & $42,387.96$ & 3.5323 \\
\hline $\begin{array}{l}\text { 7. Transportation \& } \\
\text { Communication }\end{array}$ & $24,907.45$ & 2.0756 & $28,964.29$ & 2.4137 & $32,855.01$ & 2.7379 & $38,574.73$ & 3.2146 & $20,922.13$ & 1.7435 \\
\hline $\begin{array}{l}\text { 8. Financial Interme- } \\
\text { diaries, Insurance,Real } \\
\text { Estate \& Ownerships of } \\
\text { Dwelling Business } \\
\text { Service }\end{array}$ & $18,203.84$ & 1.5170 & $21,887.63$ & 1.8240 & $26,442.21$ & 2.2035 & $31,030.23$ & 2.5859 & $16,909.30$ & 1.4091 \\
\hline 9. Services & $29,809.88$ & 2.4842 & $34,324.37$ & 2.8604 & $39,061.18$ & 3.2551 & $46,502.22$ & 3.8752 & $25,313.09$ & 2.1094 \\
\hline GRDP & $275,700.21$ & 22.9750 & $314,156.94$ & 26.1797 & $351,090.36$ & 29.2575 & $403,933.05$ & 33.6611 & $218,028.75$ & 18.1691 \\
\hline
\end{tabular}




\section{Literature Review}

The most widely known approach was advocated by Solow (1956), where he attempts to explain how an economy will grow, given its technology and the market behavior of its consumers. Based on the Solow Model the following econometric specification is used to explore factors contributing to the long run economic growth.

$$
Y_{i t}=\beta_{0}+\beta_{1} X_{1 i t}+\beta_{2} X_{2 i t}+\beta_{3} X_{3 i t}+\beta_{4} X_{4 i t}+\beta_{5} X_{5 i t}+\gamma_{t}+\delta_{i}+\varepsilon_{i t}
$$

Where $\mathrm{Y}$ is per capita GDP growth rate in country $\mathrm{i}$ and in year $\mathrm{t}, \mathrm{X}_{1}$ is the capital accumulation rate in country $i$ in year $t, X_{2}$ is the population growth rate in country $i$ in year $t, X_{3}$ is the share of research and development expenditure in country i GDP in year $t, X_{4}$ is the primary completion rate in country $i$ in year $t, X_{5}$ is the share of imports and exports in country i GDP in year $t, \gamma_{t}$ and $\delta_{i}$ are time and country fixed effects variable to capture the unobserved effects across time and countries respectively and $\varepsilon_{\mathrm{it}}$ is random error.

Many studies have examined the effect of inward FDI and imports on firm innovation, such as those of Zimmermann (1987), Veugelers and Houte (1990), Scherer and Huh (1992), Bertschek (1995), Co (2000), and Lofts and Loundes (2000). These studies find that inward FDI and imports can enhance competition and accelerate the process of innovation in the local manufacturing industry. However, only a few studies discuss the influences of outward FDI and exports on innovative activities.

Research study in Cuba, tourism play a significance role of the growth of economic. Official statistic report that at the end of 2000, there existed 29 Joint Venture in tourism with a total capital of US $\$ 1,089$ million, 26 of which were Hotel Chains managing 15,600 rooms. In the same year, 17 International Hotel chains were reported to have management and marketing contracts with Cuban counterparts.

In China, FDI inflows to the tourism sector promoted the growth of incoming tourism and consumption. Foreign investors have brought their established or potential tourist sources to the Chinese market increasing inward tourism and promoting the development of China's tourism economy. Through cooperation with foreign tourism companies, domestic ones can draw upon experience and methodology in building marketing networks and managerial practices so as to improve the overall level of China`s tourist enterprises and facilitate their internationalization process (Kyrkilis \& Pantelidis, 2003). By the year 2020, China will become the world's number one tourist destination with annual arrival 130 million.

A study by the Tourism Council of the South Pacific (1992) showed that $\$ 1,000$ of tourism expenditure in Fiji generated an output of \$3,541 in the overall economy and a total of \$336 in public sector revenue i.e. 33.6\%. This figure is on par with manufacturing and ahead of agriculture (32\%) and mining (19\%). The industry has emerged as an attractive development option with the capacity to generate significant foreign exchange earnings and incomes for the local population. It creates employment, provides revenue for government by way of direct and indirect taxes, improves infrastructure and encourages entrepreneurial activities. It also stimulates economic development through the so-called multiplier effect.

A study conducted in Australia revealed that the nation states use the capacity of national bureaucracy as a key adaptive mechanism to aid domestic accommodation of globalizing pressures while enabling the retention of state autonomy holds true, at least in the case of Australia's experience with FDI from 1968 to 2004. Thus while successive Australian governments have sought to adapt to greater internationalizing pressures, particularly those generated by international economic actors, 
such as multinational enterprises, and the internationalizing of markets, the Australian state has retained sufficient capacity to respond to such globalizing pressure to support its own strategic and political objectives. This study shows that while there are changes in how states act and behave in responding to globalizing pressures a fundamental role of the state continues to be that of regulating cross border flows such as FDI (Sadleir, 2007).

Foreign Direct Investment (FDI) in tourism would help developing countries to mitigate the effect of adverse development gap between developed and developing countries (UNCTAD, 2007). Studies of the relationship between tourism activity and FDI have been flourishing recently, but they are still scarce. Chen (2010) analysed the influence of foreign direct investment within China's tourism industry considering the imbalance of the development process across coastal and inland regions from 1978 to 2008. The results show that impacts of FDI on tourism industry in the coastal regions are greater than they are inland. Therefore, the coastal regions have experienced rapid economic and tourism development because of the inflow of FDI and political preferences. Selvanathan, Selvanathan, and Viswanathan (2012) investigated the causal link between FDI and the tourism industry in India under a VAR framework, by employing quarterly statistics from 1995 to 2007. The results indicate that a one-way causality link is found from FDI to tourism arrivals. This explains the rapid growth in the international tourism arrivals as being due to attracting further FDI in the Indian economy during the last decade.

\section{METHODS}

As previously discussed, the purpose of this research is to investigate the Foreign Direct Investment significance in tourism sector related to implications of Economic Growth in North Sumatra. Empirical analysis used FDI and GDP secondary data series collected from 2010-2014 captured with Microsoft Excel. The descriptive statistical analysis was performed by using the Statistical Program for Social Sciences (SPSS) version 21. The statistical analysis included descriptive analysis and factor analysis.

\section{RESULTS AND DISCUSSION}

The purpose of Normality Test is to test whether the dependent variable and independent variables have normal distribution or not. Figure 2 shows the graph of Normal P-Plot of the regression with dependent variable of GDP. The graph shows how the points are patterned diagonally upwards around the normal line. Therefore, this regression model fulfils the normality assumption.

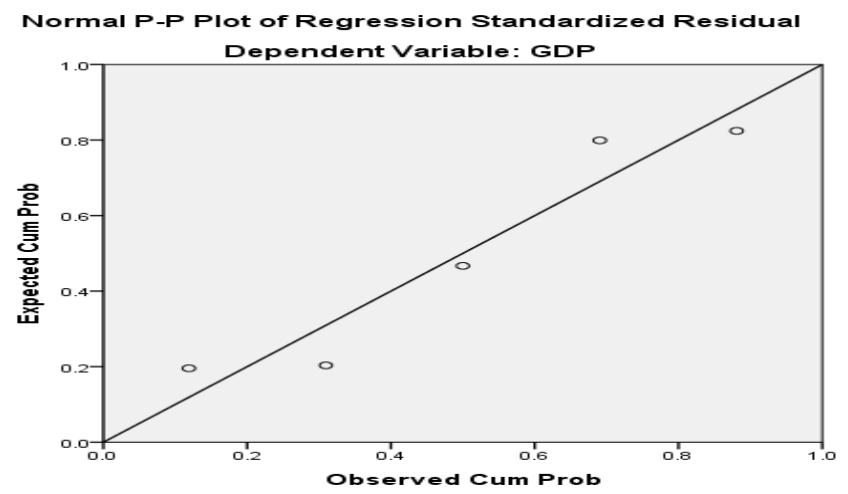

Figure 2 Regression Standardized Residual 
Regression analysis is used to determine the effect of independent variables on the dependent variable. Because the number of independent variables or $\mathrm{X}$ is only one, then the regression variables used are Simple linear regression. Simple linear regression model:

$$
Y=\beta 0+\beta 1 X 1+e
$$

where:

$$
\begin{array}{ll}
\mathrm{Y} & =\mathrm{GDP}(\text { Dependent variable); } \\
\mathrm{X} 1 & =\mathrm{FDI}(\text { Independent Variable); } \\
\beta 0 & =\text { Intercept (value of Y when all Xi }=0) ; \\
\beta 1 & =\text { regression coefficient associated with X1; } \\
\mathrm{e} & =\text { an error term. }
\end{array}
$$

Coefficient determination is used to look at the contribution of independent variable FDI (X) to dependent variable GDP (Y). The higher Adj R2, the better the regression model, as the independent variables are able to explain the dependent variable. From Table 3, the magnitude of the coefficient Adj R Square is 0.912 , it means that the variable $\operatorname{GDP}(\mathrm{Y})$ can be explained by the independent variables FDI $(\mathrm{X})$ of $91.2 \%$, while the remaining $100 \%-91.2 \%=8.8 \%$ is the contribution of the other independent variables were not included in this research, in other words FDI pretty well explain GDP. The closer R-square to 1 , the more variation of the dependent variable is being explained by the observed independent variables.

Table 3 GDP Coefficient Determination (R2)

\begin{tabular}{ccccc}
\hline Model & R & R Square & Adjusted R Square & Std. Error of the Estimate \\
\hline 1 & $.966^{\mathrm{a}}$ & .934 & .912 & .36987 \\
\hline Source: Output of SPSS & & &
\end{tabular}

The F-Test (ANOVA) is conducted to analyze the impact of the independent variables toward the dependent variable, which is GDP. To determine the rejection of the null hypothesis above; Fstatistic must exceed F-table (critical value). Aside from the F-value, $(\rho)$ value also plays a significant role; it is only when $(\rho)<0.05$, the null hypothesis may be rejected. Table 4 shows the significant value $(\rho)$ of 0.007 which is lower than $(\rho)$ critical value of 0.05 . Therefore there is significant linear correlation between FDI as the independent variables with the GDP as the dependent variable in the model, and that the independent variables are significantly influencing the dependent variable not by chance or accident. This is an indication of a fit model of regression to be significant, and thus the independent variables FDI $(\mathrm{X})$ can significantly act as predictors for the dependent variable (GDP).

Table 4 F-Test table for the regression model

\begin{tabular}{llccccc}
\multicolumn{8}{c}{ ANOVA $^{\mathbf{a}}$} \\
\hline \multicolumn{1}{c}{ Model } & Sum of Squares & df & Mean Square & F & Sig. \\
\hline Regression & 5.815 & 1 & 5.815 & 42.506 & $.007^{\text {b }}$ \\
1 & Residual & .410 & 3 & .137 & & \\
Total & 6.225 & 4 & & & \\
\hline a. Dependent Variable: GDP & & & \\
b. Predictors: (Constant), FDI & & &
\end{tabular}

Source: Output of SPSS 
Referring to column "B" in table 5 is the coefficient of each independent variable in the regression model FDI (X) towards the dependent variables (GDP) to form the regression equation. The column "t" and "Sig." represent the significance of variable and its impact on the dependent variable (GDP). Notice that the significance value $(\rho)$ of each independent variable is below 0.05 , an implication that FDI had significant impact on GDP. From column "B" in table 5, formed an equation for the regression model:

Equation 1. Linear Regression Equation FDI towards GDP

$$
\text { GDP }=3.043+0.007 * \text { FDI }
$$

Whereas the constant of the equation is 3.043 , means that when the independent variables (X) are zero, the value of GDP will be equivalent to the constant (3.043).

Table 5 Coefficient-Table for Regression

\begin{tabular}{|c|c|c|c|c|c|c|}
\hline & \multirow{2}{*}{ Model } & \multicolumn{2}{|c|}{ Unstandardized Coefficients } & \multirow{2}{*}{$\begin{array}{c}\text { Standardized Coefficients } \\
\text { Beta }\end{array}$} & \multirow{2}{*}{$\mathbf{t}$} & \multirow{2}{*}{ Sig. } \\
\hline & & B & Std. Error & & & \\
\hline \multirow{2}{*}{1} & (Constant) & 3.043 & .398 & & 7.650 & .005 \\
\hline & FDI & .007 & .001 & .966 & 6.520 & .007 \\
\hline
\end{tabular}

a. Dependent Variable: GDP

Source: Output of SPSS

\section{Hypothesis}

$\mathrm{H}_{0} \quad$ : FDI does not significantly influence GDP.

$\mathrm{H}_{1} \quad$ : FDI does significantly influence GDP.

Referring to the significance $(\boldsymbol{\rho})$ result is $0.007<0.05$, the results is a stand to reject $\mathbf{H}_{\mathbf{0}}$, this suggests that FDI does significantly influence GDP.

\section{Factors of and FDI determinants Flows to Indonesia}

\section{Strategic Location and Raw Materials}

According to BKPM (2013), with 2 million $\mathrm{km}^{2}$, sea: \pm 7.9 million $\mathrm{km}^{2}$ (4 times greater than the land), islands $>17,508$ island), Indonesia lies at the intersection of the Pacific Ocean along the Malacca straits the Indian Ocean. Over half of all International shipping goes through Indonesia waters and become a gateaway to ASEAN Market.

\section{Population and Workers Availability}

Competitive advantage in terms of worker and consumer; Indonesia is the 4th most populous country in the world accommodated 240 million people with 53\% population in cities producing $74 \%$ of GDP and 55 million skilled workers. It will generate higher buying power and availability of lower human resources price, and those will gain investor to invest in Indonesia (Kementerian Pariwisata dan Ekonomi Kreatif, 2014).

\section{Growing Middle Class and Market Demand}

Number of population in middle income (per capita expenditure per day \$2-20) with higher demands for better services and products; car sales on 2012 total to 1.116 .230 units, or increase $25 \%$ from the previous year. Analysts and industry players noted that low borrowing costs coupled with 
rising purchasing power influenced customers to buy cars. The national cement consumption reached 54,9 million tons in 2012, grew 14,3\% from 48 million tons in 2011 (BPKM,2013). In tourism sectors, The number of visitor come to Indonesia (Tourism) rose to 8,002,035 visitors in 2012, an increase of 5\% from previous year (BPKM, 2013). Foreign Equity Participation (51\% share owned by foreign investor) for the following business 1 and 2 Star Hotel, Non Classified Hotel, Motel \& Lodging Service, Home-stay, Catering, Spa, Amusement Center, Bar, Café, Singing Room/karaoke (Kementrian Pariwisata dan Ekonomi Kreatif, 2014). According to BPKM (2013), several Tourism Investment areas opportunities can be established such as: Cruise tourism, Meetings, Incentive, Convention, Exhibition/Event, Nature based and ecotourism Culture and historical based tourism Shopping and culinary, Wellness and medical tourism Recreational sports.

\section{Economic Growth}

Indonesia's 2012 growth hit $6.2 \%$ and $16^{\text {th }}$ largest economy in the world with 45 million members of the consuming class, $\$ 0.5$ trillion market opportunity in consumer services, agriculture and fisheries, resources and education (Kementerian Pariwisata dan Ekonomi Kreatif, 2014). The IMF projects Indonesia will be at the top 3 fastest economic growths among G20 countries (International Monetary Fund, 2012). Japan Credit Rating Agency (2012) stated that key factors supporting the decision of affirmation the sovereign invest in Indonesia. (1) The country's sustainable economic growth outlook underpinned by solid domestic demand, (2) low level of public debt burden brought by prudent fiscal management, (3) reinforced resilience to external shocks by its accumulated foreign exchange reserves.

Fitch Ratings in 2002 discovered that the key factors supporting the decision of affirming Indonesia's sovereign credit rating are the relatively high economic growth that is resilient to the declining global condition, high investment rate, low and declining public debt ratios and the strong overall macroeconomic policy framework. World economic forum in 2013 reported that Indonesia ranks 38th of 148 countries surveyed and remains one of the best performing countries within the developing Asia region, behind Malaysia, China and Thailand, yet ahead of Philippines, Vietnam and all South Asian nations. $100 \%$ of capital share can be owned by foreign investor for the following business: 3 to 5 Star Rated Classified Hotel; Tourism Resort, Golf Course \& Driving Range, Convention \& Exhibition.

\section{CONCLUSION}

Foreign Direct Investment in tourism sector does significantly influence its economic growth in North Sumatra. The significance value $(\boldsymbol{\rho})$ of each independent variable is below 0.05 , an implication that FDI had significant impact on GDP. There are several factors determined FDI flows to Indonesia such as Location, Availability of Employee and Raw Material, Population and Market Distribution and Economic growth indicator performance.

\section{REFERENCES}

Bertschek, I. (1995). Product and process innovation as a response to increasing imports and foreign direct investment. Journal of Industrial Economics 43(4), 341-357.

BKPM (Indonesia Investment Coordinating Board). (2013). Tourism Investments.

Chen, X. (2010). The Influence of FDI on China's Tourism Industry. Unpublished Master of Business Thesis. Auckland University of Technology. 
Endo, K. (2006). Foreign direct investment in tourism—flows and volumes. Tourism Management, $27(4), 600-614$.

International Monetary Fund. (2012). IMF World Economic Outlook Database.

Kementrian Pariwisata dan Ekonomi Kreatif. (2014). Tourism Sector Investment Realization in Indonesia Year 2010 - 2014 (Q1).

Kyrkilis, D., \& Pantelidis, P. (2003). Macroeconomic determinants of outward foreign direct investment. International Journal of Social Economics, 30(7), 827-836.

Lofts, C., \& Loundes, J. (2000), Foreign ownership, foreign competition and innovation in Australian enterprises. Melbourne Institute Working Paper No. 20/00. University of Melbourne

Sadleir, C. (2007). Australia's policy approach to Foreign Direct Investment 1968-2004 as a case study in globalization, national public policy and public administration. Thesis Doctor of Philosophy. University of Canberra.

Samimi, A. J., Sadeghi, S., \& Sadeghi, S. (2013). The relationship between foreign direct investment and tourism development: Evidence from developing countries. Institutions and Economies, 5(2), 59-68.

Scherer, F. M., \& Huh, K. (1992). R\&D reactions to high-technology import competition. Review of Economics and Statistics, 74(2), 202-212.

Selvanathan, S., Selvanathan, E. A., \& Viswanathan, B. (2012) Causality between Foreign Direct Investment and Tourism: Empirical evidence from India. Tourism Analysis, 17(1), 91-98.

Solow, R. M. (1956). A contribution to the theory of economic growth. The Quarterly Journal of Economics, 70(1), 65-94.

UNCTAD (2007). FDI and Tourism: The Development Dimension-Selected Developing Country Case-studies. United Nations, New York, NY.

UNCTAD. (2008). FDI in Tourism: The Development Dimension-UNCTAD Current Studies on FDI and Development No. 4. United Nations, Geneva.

Veugelers, R., H.P., \& Houte, V. (1990). Domestic R\&D in the presence of multinational enterprises. International Journal of Industrial Organization, 8(1), 1-15.

Xu, G. (1999). Tourism and local economic development in China: Case studies of Gruilin, Suzhou and Bedaihe. Survey UK: Curzon. P20

Zhang, J., Madsen, B., \& Jensen-Butler., C. (2007). The regional impact of tourism: The case of Denmark. Regional Studies, 41(6), 839-853.

Zimmermann, K. F. (1987). Trade and dynamic efficiency. Kyklos, 40(1), 73-87. 